Original Research Paper

\title{
Treatment of Chronic Fascioliasis in Cattle with Gelmicidum and Fascocidum
}

\author{
${ }^{1}$ Rinat T. Safiullin, ${ }^{1}$ Alexander M. Ustinov, ${ }^{1}$ Radmir R. Safiullin, ${ }^{1}$ Samat K. Shibitov, \\ ${ }^{2}$ Sergei V. Engashev and ${ }^{2}$ Ekaterin S. Engasheva
}

${ }^{1}$ All-Russian Scientific Research Institute of Fundamental and Applied Parasitology of Animals and Plants named after K.I. Skryabin-Branch FSC «VIEV》, Moscow, Russia

Innovative Center "Agrovetzashchita", Moscow, Russia

\section{Article history}

Received: 08-04-2019

Revised: 08-06-2019

Accepted: 21-06-2019

Corresponding Author: Rinat T. Safiullin

All-Russian Scientific Research Institute of Fundamental and

Applied Parasitology of Animals and Plants named after K.I.

Skryabin-Branch FSC

«VIEV», Moscow, Russia

Email: safiullin_r.t@mail.ru

\begin{abstract}
Scientific and field trials have shown a high intensity of Fasciola hepatica infection in cattle, the recommended dose of the complex preparation of Gelmicidum $7.5 \mathrm{~g}$ for every $100 \mathrm{~kg}$ of body weight is once inwardly provided extensity of efficacy of $80 \%$, intensity of efficacy of $83.8 \%$. In this case, it was quite justified to increase the therapeutic dose of the drug by $13 \%$ and assign $8.5 \mathrm{~g} / 100 \mathrm{~kg}$ of $\mathrm{b} / \mathrm{w}$, which provided a high extensity of efficacy (EE - 100\%) and intensity of efficacy (IE - 100\%). The results of the trials confirmed the previously obtained data on the efficacy EE $-96.7 \%$, IE $-97.7 \%$ of the Gelmicidum preparation in the optimal dose of $8.5 \mathrm{~g} / 100 \mathrm{~kg}$ of b/w which corresponds to a dose of $5.95 \mathrm{mg} / \mathrm{kg}$ of oxyclosanide and $17 \mathrm{mg} / \mathrm{kg}$ of albendazole according to the active substance. Fascocidum revealed $95.6 \%$ IE at the recommended dose of $10 \mathrm{mg} / \mathrm{kg} \mathrm{b} / \mathrm{w}$ at single oral administration with feed. The economic effect was 85.9 rubles per cow per day compared to the base variant in the first group (Gelmicidum) and 46.5 rubles in the second (Fascocidum) group. The total economic effect was 154.6 thousand rubles in the group of cows during the experience after treatment (3 months) compared with the base drug in the first group (Gelmicidum) and was 83.7 thousand rubles for the second group (Fascocidum).
\end{abstract}

Keywords: Cattle, Fascioliasis, Treatment, Anthelmintics, Anthelmintic and Economic Efficacy

\section{Introduction}

In our country fascioliasis in ruminant animals is registered almost everywhere except steppe and desert zones where the environmental conditions are adverse to development of fresh-water shellfish, which are the intermediate hosts of this trematodes. Lymnaea truncatula, Müller, 1774 is intermediate host for Fasciola hepatica, Linnaeus, 1758 and Lymnaea auricularia, Linnaeus, 1758 is for Fasciola gigantica, Cobbold, 1855. Infected animals are carriers of fascioles pathogen. It is well-known more than 40 species of animals, which are definitive hosts of Fasciola. Transfer factors are the grass at low land and boggy areas of grazing lands and hayfield, newly harvested hay and grazing in such places, water from puddles, ditches, bogs and other shallow pond infected by adolescaria (at the biotope zones of Lymnaea truncatula) (Skryabin and
Shults, 1937; Demidov, 1965; Kotelnikov, 1974; Sazanov, 1976; Akbaev et al., 2000; Arkhipov, 2001; Gorokhov, 2002; Postevoi, 2017).

Rainy summer has a beneficial effect on heavy increase of $L$. truncatula population and other lymneid, infecting them by fascioles eggs and appearance of adolescaria in large quantities at the grazing land. Taking into account high incidence of $F$. hepatica infection of cattle in Russia and respectively sizable economic disbenefit, which consists of deficiency of young stock $\mathrm{b} / \mathrm{w}$, decrease of dairy cow milk-production the question about quality of drugs used for their annual routine treatment is of great interest (Veselova, 1968; Antonenkov, 1974; Safiullin, 1997; Daugalieva, et al., 1999; Safiullin et al., 2006; Musaev et al., 2017; Ustinov and Safiullin, 2017).

Over the last years efforts of many researchers were aimed to study new anthelmintic drugs against fascioliasis. 
The particular attention has increased to complex Russian manufacturing medications (Scientific - Innovative center "Agrovetzashchita" of Moscow) Gelmicidum and Fascocidum worth broad-spectrum of action (Safiullin et al., 1997; Safiullin, 1998; Safiullin et al., 1999; Safiullin et al., 2004; Safiullin and Khromov, 2004; Khromov, 2005; Mkrtchan et al., 2015).

Gelmicidum is used for dehelminthization of cattle and small ruminants, it contains oxyclozanide and albendazole. Oxyclozanide (from group of salicylanilides) exhibits significant characters; it has injurious effect on all stages of development of Fasciola spp., Paramphistomum spp. and Dicrocoelium lanceatum, Stiles et Hassall, 1896. Albendazole (benzimidazole) anthelmintic is active against adult and larvae nematodes of gastro-intestinal tract and lungs and also cestodes and adult trematodes, possesses ovocidal effect. Mode of action of Oxyclozanide includes process violation of phosphorylation, decrease in activity of fumarate reductase and succinat dehydrogenases of trematodes that leads their paralysis and death. Anthelminthic effect of Albendazole is determined by carbohydrate metabolism disorder and microtubular function of helminths that courses their death. The drug administered orally quickly absorbs in gastro-intestinal tract and distributed to the site of action; it is excreted generally with urine and bile from the organism.

Fascocidum - the International name is oxyclozanide - is released in the form of pills and granules. A pill of Fascocidum containes $0.5 \mathrm{~g}$ of oxyclozanide as active pharmaceutical ingredient and auxiliary components: 0.4 $\mathrm{g}$ of potato amylum, $0.79 \mathrm{~g}$ of lactobiose, $0.08 \mathrm{~g}$ of calcium stearate and $0.03 \mathrm{~g}$ of polyvinylpyrrolidone. The drug has a significant trematodocidal effect on all stages of development of Fasciola spp., Paramphistomum spp. and Dicrocoelium lanceatum, parasiting in ruminant. Mode of action of Oxyclozanide includes abnormal process of phosphorylation, decrease in activity of fumarate reductase and succinat dehydrogenases of helminthes that leads to their paralysis and death. The drug administered orally quickly absorbs in gastrointestinal tract and distributed to many organs and tissues; it is excreted in unchanged form and in the form of metabolite generally with urine and feces with milk in lactating animals partially (Engashev, 2018).

The purpose of current work - to study anthelmintic and economical efficacy of new Russian complex manufacturing medications Gelmicidum and Fascocidum for treatment and prevention of chronic fascioliasis of cattle during recent years compared with the well-known drug Santel (the group of salicylanilides) used in Russian farm.

\section{Materials and Methods}

Total of 3 experience and one field trials was conducted to study the anthelmintic and economic efficacy in the conditions of the Kaluga region of Russia (Scheme 1). The first experiment on study of anthelmintic efficiency of medication Gelmicidum (active components oxyclozanide + albendazole) (Scientific - Innovative center "Agrovetzashchita") was conducted on naturally cows and bred heifers infected by Fasciola at different doses during January - March 2017.

According to the results of feces examination by subsequent washing method 50 cows were selected out of 267 cows of black-and-white and hereford breeds at the age from 2.5 to 6 years infected with chronic $F$. hepatica and body weight from 280 to $530 \mathrm{~kg}$ and divided into five equal groups at 10 animals in each group. The number of eggs of $F$. hepatica in $1 \mathrm{~g}$ of feces of infected cows was counted using a counting chamber of Mac Masters.

Gelmicidum was administered to the Animals of the first - fourth groups in the form of granules at the doses of $6.5,7.5,8.5$ and $9.5 \mathrm{~g}$ per $100 \mathrm{~kg}$ of $\mathrm{b} / \mathrm{w}$ respectively, that equivalent to active component of oxyclozanide 4.6, 5.25, 5.95 and $6.65 \mathrm{mg} / \mathrm{kg}$ and of albendazole $13,15,17$ and 19 $\mathrm{mg} / \mathrm{kg}$. Animals of the control group were without treatment. The results were considered in 30 and 60 days.

The second experiment. Comparative efficacy of Gelmicidum and Fascocidum was studied at the farm in Ferzikovskiy district of the Kaluga region during February - April, 2017. According to the data of helminthoovoscopic investigations conducted by the subsequent washing and methods of Vishnyaskas 30 from 234 cattle at the age from 18 months to 5 years with $\mathrm{b} / \mathrm{w}$ of $350-500 \mathrm{~kg}$ were selected. Animals were renumbered and divided into three equal groups at 10 animals in each group.

Gelmicidum was given to the cows from the first group in the form of granules at the doses of $8.5 \mathrm{~g} / 100$ $\mathrm{kg}$ of $\mathrm{b} / \mathrm{w}$, that equivalent to $5.95 \mathrm{mg} / \mathrm{kg}$ of oxyclozanide and $17 \mathrm{mg} / \mathrm{kg}$ of albendazole. The second group received Fascocidum at the dose of a pill per $50 \mathrm{~kg}$ of $\mathrm{b} / \mathrm{w}$, that equivalent to $1 \mathrm{~g}$ of oxyclozanide per $100 \mathrm{~kg}$ of $\mathrm{b} / \mathrm{w}$ or active component at the dose of $10 \mathrm{mg} / \mathrm{kg}$ orally at single administration with feed in the morning. Animals of the control group were in similar conditions but the did not receive drug.

Anthelmintic efficacy of Gelmicidum and Fascocidum was tested in natural fascioliasis of cattle under field conditions tested on the farm in the Kaluga region from January to March, 2018. Particular commercial farm was unfavorable fore helminthoses; all livestock are grazed in summer except 6 months calves. As the result of investigation 60 infected animals out of 278 cows and bred heifers at the age from 16 months to 6 years and body weight from 280 to $500 \mathrm{~kg}$ were selected and divided into two groups of 30 animals in each group. Their housing and feeding conditions were the same. 
Gelmicidum was administered to the animals of the first group with feed in the form of granules at the dose of $8.5 \mathrm{~g}$ per $100 \mathrm{~kg}$ of $\mathrm{b} / \mathrm{w}$; Fascocidum was administered to the second group at the dose of a pill per $50 \mathrm{~kg}$ of $\mathrm{b} / \mathrm{w}$ mandatory with help of pills-giver. Within a given period these pills were given them again and more water by means of rubber bottle. Efficacy of performed treatment was established in 30 and 60 days after drugs administration.

Economic efficacy of administration of Gelmicidum and Fascocidum was determined in comparison with standard medication Santel 10\% (closantel) in cattle with of natural fascioliasis. Experiments were conducted in one of the commercial farm in Ferzikovskiy district of the Kaluga region during January - April, 2017. As a result of feces examination by washing method, 60 cows out of 215 of the second - fifth lactation with an average body weight of $450 \mathrm{~kg}$ were selected. Animals were divided into three similar groups at 20 animals in each group at taking into account average number of Fasciola eggs in $1 \mathrm{~g}$ of feces $(\mathrm{p}>0.05)$. The conditions of housing and feeding of the experimental animals were the same

Cows of the first group received Gelmicidum once with feed in the form of granules in previously determined optimal dose of $8.5 \mathrm{~g}$ per $100 \mathrm{~kg}$ of $\mathrm{b} / \mathrm{w}$; cows of the second group received Fascocidum at the dose of $10 \mathrm{mg}$ per $1 \mathrm{~kg}$ (1 pill per $50 \mathrm{~kg}$ ). Necessary for each animal quantity of pills were milled into powder and mixed with feed. Animals of the third group were administered $10 \%$ Santel intramuscularly at the dose of active component $5 \mathrm{mg}$ per $1 \mathrm{~kg}$ or $0.5 \mathrm{ml}$ per $10 \mathrm{~kg}$ of $\mathrm{b} / \mathrm{w}$ at single administration.

Efficacy of performed treatment was established according to the results of feces examination of cows in 30 and 60 days after giving drugs. The milk productivity of cows of different groups was taken into account daily, as well as according to the data of control milks, which were carried out monthly.

Experimental efficacy data on the number of $F$. hepatica eggs in $1 \mathrm{~g}$ of feces obtained during the study were subjected to statistical analysis using the method of Plokhinsky (1978) with the definition of their significance. Statistical analysis of data was evaluated by using SAS/Stat (version №9 of the SAS System for Windows) software.

\section{Results}

We did not observe any complications during the period of cows treatment by distinct dose of Gelmicidum and during following 7 days. They had eaten feed with anthelmintic well, occasionally it had been left less then $50 \mathrm{~g}$. In 30 days 6 animals from the first group were free from Fasciola. Initially average 96 Fasciola eggs were detected in $1 \mathrm{~g}$ of their feces (intensity of infection) and after treatment with Gelmicidum at the dose of $6.5 \mathrm{~g}$ per $100 \mathrm{~kg}$ of b/w 35 eggs were revealed. Extensity of efficacy (EE) at this dose was $60 \%$ and intensity of efficacy (IE) was $63.6 \%$. In 30 days 8 animals from the second group were free from Fasciola. Initially 105 eggs were in the second group and 17 eggs after treatment at the dose of $7.5 \mathrm{~g}$ per $100 \mathrm{~kg}(\mathrm{p}<0.05)$. While EE was $80 \%$ and IE was $83.8 \%$. All animals from the third and the fourth groups were free from Fasciola (EE is 100\%). Before treatment average number of Fasciola eggs in $1 \mathrm{~g}$ of feces was 112 and 115 respectively and they were not detected after administration of Gelmicidum at doses of 8.5 and $9.5 \mathrm{~g}$ per $100 \mathrm{~kg}$ of b/w (IE $100 \%$ ). All 10 cows of control group were infected by Fasciola in 30 days (EI is - $100 \%$ ). Initially 92 eggs were detected and in 30 days there were 95 eggs.

Animals of experimental and control group were examined repeatedly in 60 days after treatment. The eggs of $F$. hepatica were revealed in 4 (EI is $40 \%$ ) and 2 (EI is $20 \%$ ) animals respectively in the first and in the second group. Cows from the third and the fourth group were free from this type of helminth. All animals of control group were infected by Fasciola (EI - 100 \%). Average number of eggs of Fasciola in $1 \mathrm{~g}$ of animals' feces of the first, the second and the control group increased on $5-7 \%$ (2 -7 samples).

At the end of experiment Gelmicidum was administrated to all cows of the control group and 4 cows of the first group and 2 cows of the second group at optimal dose of $8.5 \mathrm{~g} / 100 \mathrm{~kg}$ of $\mathrm{b} / \mathrm{w}$ in feed once in the morning repeatedly. According to data of feces examination animals were fully free from Fasciola infection in 30 days (EE is $100 \%$ ).

At the second experiment on testing comparative efficacy of Gelmicidum and Fascocidum we were not registered any complications during the period of treatment of fascioliasis. They had fed anthelmintic well. During the treatment period and after 10 days adverse action on animals were not observed according to clinical and hematological studies, the cows eated the food with anthelmintics well. The amount of uneated ranged from 20 to $30 \mathrm{~g}$.

In 30 days all cows of the first group, which received the recommended dose of Gelmicidum, were free from Fasciola (EE - 100\%). In the second group 9 animals were fully free from helminths (EE - 90\%). The average number of Fasciola eggs in $1 \mathrm{~g}$ of feces of animals of the first group before treatment was 121 examples and 0 ex. after treatment. IE of Gelmicidum was $100 \%$. The average number of eggs of Fasciola in $1 \mathrm{~g}$ of faeces of animals from the second group before treatment was 119 samples and 7 samples after treatment $(p<0.05)$. IE was $94.1 \%$. Extensity of efficacy was $90 \%$. The average number of Fasciola eggs in $1 \mathrm{~g}$ of feces of animals of the control group was 118 examples. Gelmicidum was given at the dose of $8.5 \mathrm{~g}$ per $100 \mathrm{~kg}$ of $\mathrm{b} / \mathrm{w}$ after 2 months initial administration of Fascocidum to infected animal and all cows of control group. In the process of feces examination all repeatedly treated cows were free from Fasciola in 30 days (EE - 100\%) (Ref. Table 1). 
Table 1: The anthelminthic and economic efficacy of Gelmicidum and Fascocidum in chronic fasciolosis of cows and heifers in experience and in the field trials

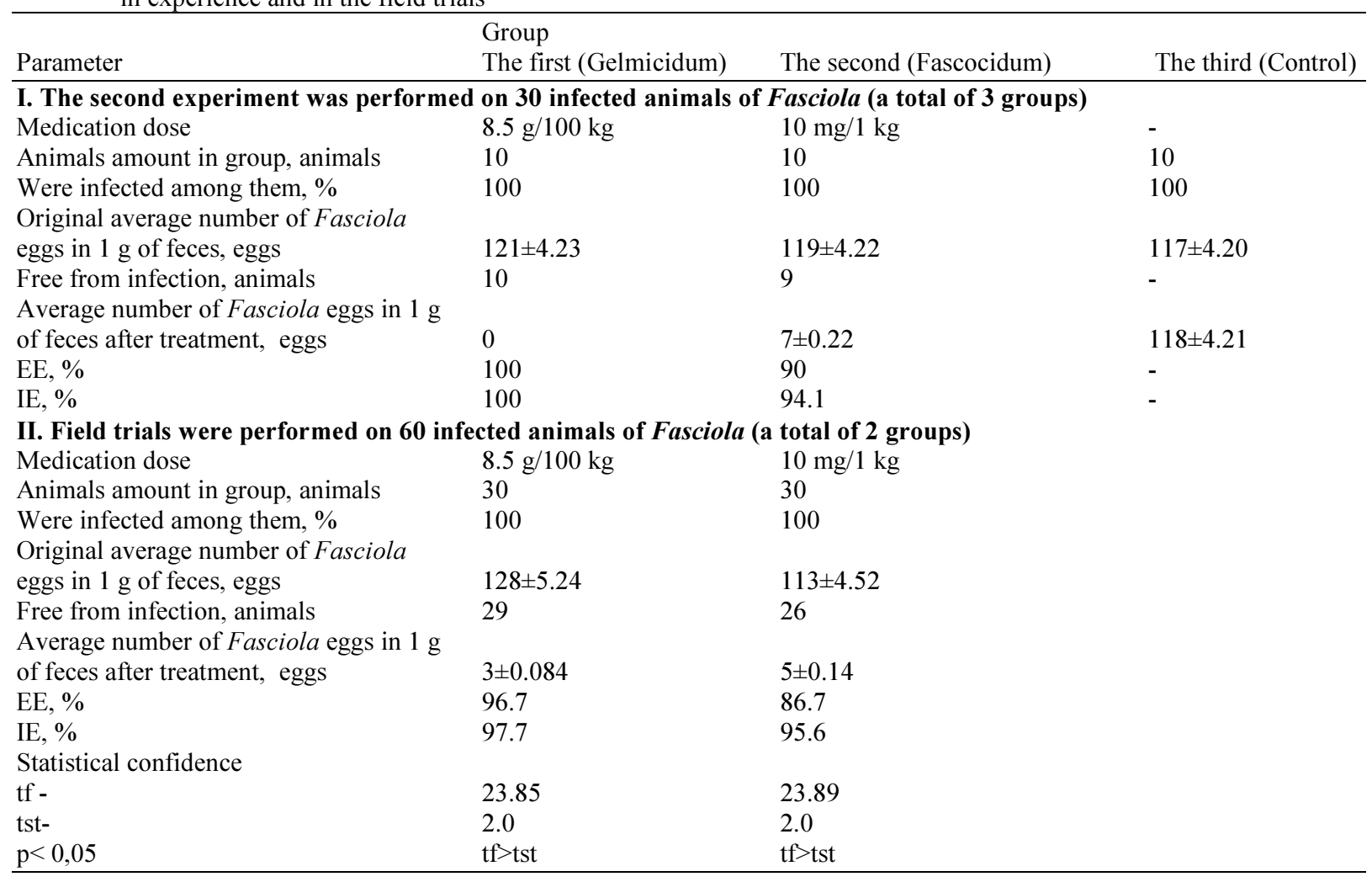

Table 2: Economical efficacy of antifascioliasis arrangements

\begin{tabular}{|c|c|c|c|}
\hline $\begin{array}{l}\text { Parameter } \\
\text { Medication dose }\end{array}$ & $\begin{array}{l}\text { Group } \\
\text { The first } \\
\text { (Gelmicidum) } \\
8.5 \text { g per } 100 \mathrm{~kg}\end{array}$ & $\begin{array}{l}\text { The second } \\
\text { (Fascocidum) } \\
10 \text { mg per } 1 \mathrm{~kg}\end{array}$ & $\begin{array}{l}\text { The third (Santel) } \\
5 \mathrm{mg} \text { per } 1 \mathrm{~kg}\end{array}$ \\
\hline Necessary amount of drug for treatment of 1 cow & 38.2 & 18 & 22.5 \\
\hline Price of $1 \mathrm{~kg}$ of drug, RUR & 1453 & 939 & 1760.0 \\
\hline Treatment coast of 1 cow during the course, RUR & 55.5 & 21.1 & 39.6 \\
\hline Animals amount in group, animals & 20 & 20 & 20.0 \\
\hline Were infected among them, $\%$ & 100 & 100 & 100.0 \\
\hline Free from infection, animals & 20 & 19 & 18.0 \\
\hline $\mathrm{EE}, \%$ & 100 & 95 & 90.0 \\
\hline $\mathrm{IE}, \%$ & 100 & 97.6 & 93.4 \\
\hline $\begin{array}{l}\text { Average milk production of cow after treatment, } \mathrm{kg} \\
\text { initially }\end{array}$ & 11.5 & 12.1 & 10.8 \\
\hline One month from today & 13.8 & 12.9 & 11.7 \\
\hline Two months from today & 14.9 & 14.1 & 13.2 \\
\hline Three months from today & 16.8 & 16.2 & 14.1 \\
\hline Increase of milk production after 3 months, $\mathrm{kg}$ & 5.3 & 4.1 & 3.3 \\
\hline $\begin{array}{l}\text { Coast of daily milk production, RUR: } \\
\text { on } 1 \text { cow }\end{array}$ & $\begin{array}{l}185.5 \\
3710\end{array}$ & $\begin{array}{l}143.5 \\
2870\end{array}$ & $\begin{array}{r}115.5 \\
2310\end{array}$ \\
\hline $\begin{array}{l}\text { on the group } \\
\text { Economical effect of medication comparison } \\
\text { with standard variant, RUR: }\end{array}$ & 3710 & 2870 & 2310.0 \\
\hline on 1 cow & 85,9 & 46,5 & - \\
\hline on the group & 1718 & 930 & - \\
\hline on the group after 3 months, thous. & 154.6 & 83.7 & - \\
\hline
\end{tabular}


At the field trials the results of coproscopy showed that 29 out of 30 naturally infected cows and heifers from the first group, were free from Fasciola. The extensity of efficacy is $96.7 \%$. The average number of Fasciola eggs in $1 \mathrm{~g}$ of feces of animals of the first group before treatment was 128 examples and 3 ex. after treatment. IE of Gelmicidum was $97.7 \%$. In the second group 30 animals were infected with Fasciola, after treatment with the recommended dose of Fascocidum, 26 animal were free from Fasciola. Extensity of efficacy was $86.7 \%$. The average number of eggs of Fasciola in $1 \mathrm{~g}$ of faeces of animals from the second group before treatment was 113 samples and 5 samples after treatment. IE was $95.6 \%$.

Any deviation were not observed in the process of definition of economic efficacy of administration of Gelmicidum, Fascocidum and Santel to the animals. All 20 animals of firth group, which received Gelmicidum (EE - $100 \%$ ), 19 animals of second group, which received Fascocidum (EE - 95\%, IE - 97.6\%) and 18 animals of thirty group, which received Santel (EE - 90 $\%$, IE - $93.4 \%$ ) were free from Fasciola (Ref. Table 2). While the number of eggs of Fasciola in $1 \mathrm{~g}$ of different groups of animals feces initially varied from 103 to 126 examples.

In 30 and 60 days after treatment the results were similar.

Economical effect was determined by the result of drugs administration of Gelmicidum, Fascocidum and Santel and was calculated according to a formula:

$$
E a a=[(C t-C c)+(G P c-G P t)]+A n,
$$

where, Eaa is an economical efficiency of antifascioliasis arrangements with administration of new drugs, RUR; $C c$ is current manufacturing coast in an amount on one cow in trial (new) and $C t$ is control (standard) variant, $R U R$; $G P c$ and $G P t$ is gross production coast of cattle breeding (milk), accessed during the experiment in trial and control variant respectively, $R U R ; A n$ is cow population treated by new drug.

Cows' milk production was estimate according to the results of control milking operations, which were conducted at the beginning of the experiment and then in 1, 2 and 3 months after drugs administration.

Following basic data were used for calculation: 1453 RUR is the price for $1 \mathrm{~kg}$ of Gelmicidum granulates, 939 RUR is the price for $1 \mathrm{~kg}$ of Fascocidum and 1760 RUR is the price for $1 \mathrm{~kg}$ of 10 $\%$ Santel. Purchasing price of $1 \mathrm{~kg}$ cows' milk is 35 RUR at this commercial farm.

Treatment coast on 1 animal during the course of treatment by Gelmicidum was 55.5 RUR, by Fascocidum was 21.1 RUR and by Santel was 39.6 RUR.
Initially average daily milk production of cows of the first group was $11.5 \mathrm{~kg}$, of the second group was $12.1 \mathrm{~kg}$ and of the third group was $10.8 \mathrm{~kg}$; in a month after treatment $13.8,12.9$ and $11.7 \mathrm{~kg}$; in two months $14.9,14.1$ and $13.2 \mathrm{~kg}$ and in 3 months $16.8,16.2$ and $14.1 \mathrm{~kg}$ respectively.

After 3 months this parameter was $5.3 \mathrm{~kg}$ in the first group, $4.1 \mathrm{~kg}$ in the second group and $3.3 \mathrm{~kg}$ in the third group. It consisted on a cow 185.5, 143.5 and 115.5 RUR respectively; on the group 3710 RUR, 2870 RUR and 2310 RUR.

Economical Effect (EA) accessed as the result of conduction of therapeutic measures on one animal of the first group was 85.9 RUR per day in comparison with the third group; 46.5 RUR was on the second group. EA was 1718 and 930 RUR per day respectively on the group of animals; 154.6 thous RUR and 83.7 thous RUR per 3 months respectively on the group during the experiment.

\section{Discussion}

The results of our research showed that cows and heifers were spontaneously infected with Fasciola hepatica on the farms in the Central region of Russia. Our data are consistent with the reports of other authors (Akbaev et al., 2000; Gorokhov, 2002).

Animals infected with chronic $F$. hepatica are observed in farms due to the insufficient efficacy of the anthelmintics used. And also because the intermediate hosts infected with larvae of Fasciola constantly present on the pastures.

The test results of the anthelmintic activity of Fascocidum against adult $F$. hepatica are consistent with the data of Arkhipov (2009; Mkrtchan et al., 2015). The anthelmintic efficacy of the combined preparation of a Gelmicidum depends on its dose. A dose recommended by the manufacturer demanded an upward dose adjustment.

Scientific and field trials have shown a high intensity of Fasciola hepatica infection of cattle, the recommended dose of the complex drug of Gelmicidum $7.5 \mathrm{~g}$ for every $100 \mathrm{~kg}$ of $\mathrm{b} / \mathrm{w}$ is once inwardly provided extensity of efficacy $-80 \%$ and intensity of efficacy-83.8\%.

The research conducted on the 30 day after treatment of animals of the third and fourth groups that received Gelmicidum in doses of $8.5 \mathrm{~g}$ and $9.5 \mathrm{~g}$ per $100 \mathrm{~kg}$ of b/w revealed that they were free from Fasciola (extensity of efficacy $-100 \%$ ). The optimal dose of Gelmicidum was $8.5 \mathrm{~g}$ per $100 \mathrm{~kg}$ of $\mathrm{b} / \mathrm{w}$ at single feeding in the morning with the combined animal feed. 
Fascocidum showed $95 \%$ of EE and $97.6 \%$ IE used individually in field trial at the dosage recommended by the manufacturer of $10 \mathrm{mg} / \mathrm{kg}$ ( 1 pill per $50 \mathrm{~kg}$ of weight).

Gelmicidum provided $96.7 \%$ of EE and $97.7 \%$ of IE at the dose of $8.5 \mathrm{~g} / 100 \mathrm{~kg}$ of $\mathrm{b} / \mathrm{w}$ in field conditions. The EE and IE of Fascocidum was $86.7 \%$ and $95.6 \%$ of efficacy at recommended dose of $10 \mathrm{mg} / \mathrm{kg}$ of b/w.

Observations carried out during the treatment of animals and after it showed that the cows satisfactorily tolerated to Gelmicidum and Fascocidum in tested doses, with no cases of complicating disorders.

\section{Conclusion}

Gelmicidum and Fascocidum did not cause side effects they had eaten medicated-feed well under the field conditions.

The extensity of efficacy and intensity of efficacy of Gelmicidum was $96.7 \%$ and $97.7 \%$ respectively at the optimal dose of $8.5 \mathrm{~g}$ per $100 \mathrm{~kg}$ of $\mathrm{b} / \mathrm{w}$ single oral administration. Fascocidum showed $86.7 \%$ of EE and $95.6 \%$ of IE at the dose of $10 \mathrm{mg}$ per $1 \mathrm{~kg}$ of $\mathrm{b} / \mathrm{w}$ with feed single.

\section{Acknowledgments}

The authors express their gratitude to the drug manufacturer the Scientific and Innovation Center Agrovetzashchita for the submitted test samples and veterinary specialists of the Kaluga region for their assistance in testis.

\section{Funding Information}

This study was supported by the Federal State Budgetary Institution of Science All-Russian Scientific Research Institute of Fundamental and Applied Parasitology of Animals and Plants named after K.I. Skryabin.

\section{Author's Contributions}

Rinat T. Safiullin: Study of animals before and after treatment.

Alexandr M. Ustinov: Animal Drug Testing.

Radmir R. Safiullin: Animal Drug Testing.

Samat K. Shibitov: Study of animals before treatment.

Sergei V. Engashev: Creation of medicinal forms of drugs gelmicidum and fascocidum.

Ekaterina S. Engasheva: Manufacturing of medicinal forms.

\section{Ethics}

This review is original and was not published elsewhere. It can be confirmed that all authors have read and approved the manuscript and no ethical issues involved. The authors declare that they have no conflict of interest.

\section{References}

Akbaev, M.S., A.A. Vodyanov and N.I. Kosminkov, 2000. Parasitology and Animals Invasion Disease. 1st Edn., Moscow, pp: 743.

Antonenkov, I.P., 1974. Economic damage caused by fascioliasis. Veterinary, 2: 82-84.

Arkhipov, I.A., 2001. Intercourse of fascioles and their hosts at the south-east region of the North Caucasus. Proceedings of the Scientific Conference "Theory and Practice of Antiparasitic Diseases", May 16-18, Russia, pp: 17-18.

Arkhipov, I.A., 2009. Anthelmintics: pharmacology and application, Moscow, pp: 405.

Daugalieva, E.K., S.A. Shemyakova and K.G. Kurochkina, 1999. Combined therapy in the case of fascioliasis of cattle. Proceedings of the Scientific Conference "Theory and Practice of Antiparasitic Diseases", May 12-14, Russia, pp: 78-79.

Demidov, N.V., 1965. Fascioliasis of Animals, Moscow, pp: 207.

Engashev, S.V., 2018. Catalog of Veterinary Drugs For Health For Farm Animals. Agrovetzashchita, pp: 160 .

Gorokhov, V.V., 2002. Fascioliasis as a serious environmental problem. Proceedings of the Scientific Conference "Theory and Practice of Antiparasitic Diseases", May 15-17, Russia, pp: 97-100.

Khromov, K.A., 2005. Fascioliasis and Strongylatosis of Gastro-intestinal tract of cattle under the Conditions of Central zone of Russia and Searching effective means protection from them. Synopsis of a dissertation for the degree of Dr. of Vet. Sci., Russia, pp: 22.

Kotelnikov, G.A., 1974. Diacrisis of Animals. Helminthiasis, Moscow, pp: 240.

Mkrtchan, M.E., S.O. Movsenyan and E.S. Klimova, 2015. Evaluation of fascocidum efficiency in the case of dicroceliasis and its associations. Mater. of the report of scientific conference "Theory and practice of antiparasitic diseases", Moscow, 16: 263-265.

Musaev, M.B., M.S. Khalikov, M.V. Milenina, A.Z. Dzhamalova and K.h.I. Bersanova, 2017. Commission testing of the supramolecular complex of triclabendazole during sheep fascioliasis. Proceedings of the Scientific 
Conference "Theory and practice of antiparasitic diseases", May, 18: 293-296.

Plokhinsky, N.A., 1978. Mathematical methods in biology. Moscow, pp: 265.

Postevoi, A.N., 2017. Modeling of Fascioliasis In Laboratory Animals. Proceedings of the Scientific Conference "Theory and practice of antiparasitic diseases", May, 18: 361-364.

Safiullin, R.T. and K.A. Khromov, 2004. Afascil or Alben-super. Vet. Physic., 2: 67- 69.

Safiullin, R.T., 1997. Extension and economic damage of major helminthiasis of ruminants. Vet., 6: 28-32.

Safiullin, R.T., 1998. Levacid in the case of fascioliasis of cows and sheep. Vet., 5: 27-29.

Safiullin, R.T., A.K.h. Volkov and G.N. Gaysin, 1997. Vermitin efficiency in the case of combined Animals' helminthiasis. Proceedings of the Scientific Conference on the diacrisis and treatment of farm Animals disease, May, pp: 140-141.

Safiullin, R.T., A.M. Sazonov, K.A. Khromov and M.A. Musatov. 2006. Methodological recommendations on determination of economical efficiency of antiparasitic arrangements and results of scientific-research works, Moscow, pp: 42.

Safiullin, R.T., E.N. Burmistrov and A.K.h. Volkov, 1999. Santel is the high efficiency medication in the case of parasitic disease of cattle. Vet., 5: 33-35.

Safiullin, R.T., K.A. Khromov and O.A. Bespalov, 2004. Rolenole in the case of fascioliasis and strongylatosis of cattle. Vet., 10: 10-11.

Sazanov, A.M., 1976. Biological foundation of fascioliasis prophylaxis under the conditions of watering and reclamation of land. Synopsis dissertation degree Dr. Vet. Sci., Russia, pp: 463.

Skryabin, K.A. and R.S. Shults, 1937. Helminthiases of cattle and its young stock, Moscow, pp: 723.

Ustinov, A.M. and R.T. Safiullin, 2017. Fascioliasis in slaughter cattle in the Kaluga region. Proceedings of the Scientific Conference "Theory and Practice of Antiparasitic diseases", May, 18: 499-501.

Veselova, T.P., 1968. Fasciolocide anthelmintics carbon tetrachloride, carbon hexachloride and hexachloroparaxylene: Synopsis of a dissertation for the degree of Dr. of Vet. Sci., Russia, pp: 46.

Scheme 1: The study of anthelminthic and economic efficacy of Gelmicidum and Fascocidum in chronic fasciolosis of cows and heifers

The first experiment was carried out on 50 infected animals of Fasciola (a total of 5 groups). Testing of different doses of Gelmicidum was conducted on 4 experimental and one control groups of animals.

The second experiment was performed on 30 infected animals of Fasciola (a total of 3 groups). A test of the optimal doses of Gelmicidum, a Fascocidum was made on 2 experimental groups and one control groups of animals.

Field trials were performed on 60 infected animals of Fasciola (a total of 2 groups). Testing of the different doses of Gelmicidum and Fascocidum was conducted.

Field trials were performed on 60 infected animals of Fasciola (a total of 2 groups). Testing of the different doses of Gelmicidum and Fascocidum was conducted. 